\title{
Education, Service Quality, Accountability, Awareness, and Taxpayer Compliance: Individual Taxpayer Perception
}

\author{
Vince Ratnawati ${ }^{1}$, Ria Nelly Sari $^{1} \&$ Zuraidah Mohd Sanusi ${ }^{2}$ \\ ${ }^{1}$ Faculty of Economics and Business, Universitas Riau, Pekanbaru, Indonesia \\ ${ }^{2}$ Accounting Research Institute, Universiti Teknologi MARA, Malaysia \\ Correspondence: Vince Ratnawati, Jalan Teratai Atas, No. 125, Pekanbaru, Indonesia.
}

Received: April 30, 2019

doi:10.5430/ijfr.v10n5p420
Accepted: May 30, 2019

Online Published: June 11, 2019

URL: https://doi.org/10.5430/ijfr.v10n5p420

\begin{abstract}
The aim of this study is to investigate how education, service quality, and accountability affect taxpayer compliance and awareness. A model was developed and tested by using a sample of 253 taxpayers listed on the Directorate General of Taxation in Riau, Indonesia. Data were collected and analyzed by using least squares regression and moderated regression analyses. Results show that education, service quality, and accountability affect taxpayer compliance. The results also indicate that tax awareness strengthen the effects of education, service quality, and accountability on taxpayer compliance.
\end{abstract}

Keywords: education, service quality, accountability, awareness, taxpayer compliance

\section{Introduction}

Currently, the revenue of Indonesian government is largely derived from tax revenue. Therefore, the government should make efforts so that the target revenue can be achieved. To increase tax revenue, taxpayers should be aware of their tax obligations. However, tax revenue in Indonesia has never reached a predetermined target, which indicates the lack of taxpayer compliance in carrying out their tax obligations. This claim is evident in the failure of taxpayers in reporting their annual tax returns, which is supposed to be one of their obligations. In 2016, the taxpayers' annual submission compliance ratio target was $72.5 \%$, but the realization only reached $63.15 \%$ (attachment from the Ministry of Finance Performance Report 2016). Taxpayer compliance is nonoptimal in carrying out tax obligations in paying taxes, which can also be seen from the achievement of the tax revenue target determined by the government. Based on data from the Directorate General of Taxation, the realization of tax revenue in 2016 only reached $83.4 \%$.

Various efforts through policies and regulations have been made by the government to increase tax revenue. For example, in 2016, the government passed a tax amnesty law for taxpayers who have not reported assets acquired until 2015, without being penalized. However, they will pay redemption money in accordance with applicable rules. This effort aims to motivate taxpayers to transparently report their income and improve taxpayer compliance.

The burden to be borne by the Directorate General of Taxes continues to become more severe with the majority of revenues in the Indonesian Budget (APBN) largely derived from tax revenue. This situation is evident in the annual increase of tax revenue target for APBN. Table 1.1 shows an increase in tax revenue targets in the APBN from 2011 to 2016.

Although the government has implemented various ways and policies to increase tax revenue, the government's target has not been achieved yet, and the tax ratio is still low. Moreover, the income sourced from taxation is still quite low. Low tax revenue can affect gross domestic product, which only reached $10.3 \%$ and is the lowest ratio in the world, whose standard average is $15 \%$. However, the ratio is not too low compared with the government's target tax ratio of $10.9 \%$ in the present year. Low tax revenue or the non-fulfillment of the government-set target revenue is probably caused by the low level of taxpayer compliance in carrying out their tax obligations.

Therefore, the efforts that must be done to increase tax revenue should be explored. One way that can be done to increase tax revenue is to improve taxpayer compliance and public awareness in carrying out their obligations. One of the efforts made by the Director General of Taxes to improve taxpayer compliance is to maintain tax awareness. This program is also known as the Tax-Awareness Education Program. The program was initiated by the Indonesian 
Directorate General of Taxation in cooperation with education stakeholders. The program aims to instill tax awareness by integrating its value in the national education system through curriculum, learning, bookkeeping, and student affairs (Ministry of Finance, Directorate General of Tax, 2016).

The objective of the program is to create a tax-conscious culture from an early age to build the future of Indonesian taxation and create the next generation that will defend and love the country by carrying out tax obligations properly and correctly (Ministry of Finance, 2016). The impact of Tax-Aware program is expected to foster tax awareness on the community. The concept is to include tax inclusion in the education curriculum, starting from early childhood, elementary, junior high school, high school, and up to college. If the tax awareness of each taxpayer grows, then their compliance in carrying out tax obligations will also grow. Thus, the factors that can increase tax awareness should be identified and studied.

Various studies have examined different factors that affect tax awareness. Gitaru (2017) found that improving the level of tax compliance requires skills and knowledge gained through education and trainings. Other researchers, such as Machogu and Amayi (2013), also found that taxpayers' level of education affects their level of compliance in paying taxes. The higher the level of understanding of the taxpayer, the higher the level of taxpayer compliance. Contrary, Lilisen, Ratnawati, and Indrawati (2018) found that accountability does not affect tax compliance (Nurulhuda, Hasan \& Mohd 2018).

In addition, service quality has an important role in improving taxpayer compliance. If the services of the government are proven useful and satisfy taxpayers, then they will comply with applicable rules. Accountability also plays an important role in influencing taxpayer compliance. If taxpayers perceive that accountability has been met, then predicted taxpayer compliance will increase. This argument is in accordance with the findings of Adeyeye and Otusanya (2015) who found that accountability has a positive effect on tax compliance. These findings also indicate that the more accountable the tax institutions, the higher the level of tax compliance.

Savitri and Musfialdy (2016); Negrut, (2017) found that the effects of tax awareness on tax compliance are mediated by service quality. Their findings indicate that service quality provided by tax authorities to taxpayers affect taxpayer compliance. The higher the level of tax awareness, the more obedient the taxpayers in carrying out their tax obligations

\section{Literatur Review}

\subsection{Agency Theory}

Agency theory states that a separation should exist between control activities and operational activities. In this case, a Board of Directors should exercise control of the company's operations and a Board of Management (CEO) should conduct operations of the company. Based on the agency theory, individuals or groups involved in value maximization intersect with interests that bring about organizational conflicts (Kast \& Rosenzweigh, 2002). Kim \& Lee (2003) classifies the three types of agency problems, namely, conflict of interests between shareholders and managers (agency costs of equity) (Jensen, 1976), conflict of interests between controlling shareholders and minority shareholders (La Porta et al., 2000), and conflict of interests between shareholders and bondholders (agency costs of debt) (Jermsittiparsert \& Sriyakul, 2014; Jensen and Meckling, 1976; Nejad, et.al 2017).

Eisenhardt (1989) states that the agency theory uses three assumptions of human nature: (1) human beings are generally self-interested, (2) human beings have limited thinking about bounded rationality, and (3) humans always avoid risk (risk averse). In the context of this study, conflicts of interests occur between tax authorities and taxpayers. The principle of self-assessment in the tax system results in more taxpayers having information about the condition of the company compared with the tax itself. Given the conflict of interests among taxpayers, they want to explore the potential of taxpayers in paying taxes as much as possible. At the same time, they want to pay taxes as small as possible. By contrast, because tax authorities have less information on the personal data of taxpayers, the latter (as agents) hide information from the tax authorities to achieve their personal interests.

\subsection{Attribution Theory}

Attribution is a process of forming an impression, and it refers to the way people explain the cause of the behaviors of others or themselves. Attribution is also a process of drawing conclusions about factors that affect the behaviors of others. Attribution theory tries to discover what causes what or what drives what someone does. Men respond to an event according to their interpretation of the occurrence of an event (Harold Kelley, 1967).

According to the attribution theory, when individuals observe a person's behavior, they will try to determine whether the behavior is internal or external (Robbins, 1996). Internal behavior occurs under individual personal control itself 
or is derived from internal factors, such as personality traits, awareness, and ability. Meanwhile, external behavior is caused by external or outside factors.

The attribution theory can be attributed to taxpayer compliance to pay taxes as it relates to taxpayers' perceptions in making an assessment of the tax itself. A person's perception of making judgments about something is strongly influenced by the internal and external conditions of the person. Therefore, the theory is very relevant in explaining taxpayer intention.

\subsection{Previous Studies}

A person can increase his knowledge through education. Education also has an impact on the increased adherence of a person in implementing rules because he has sufficient knowledge about them. Muklis, Utomo, and Susetio (2015) found that education in the field of taxation can increase the knowledge of taxpayers, thereby increasing taxpayer compliance in carrying out their tax obligations.

Gitaru (2017) found that increasing tax compliance requires skills and knowledge gained through education and trainings, which means that the higher the knowledge of taxpayers, the more obedient the taxpayers in implementing the rule. Other researchers, such as Machogu and Amayi (2013), also found that taxpayers' level of education may affect their level of compliance in paying taxes. The higher the level of understanding of taxpayers, the higher their level of compliance in paying taxes.

Quality of service also plays an important role in improving taxpayer compliance. If the services received by taxpayers from the government are good enough and satisfy them, then taxpayers will comply with the applicable rules. This statement is in accordance with the findings of Alabede, Idris, and Affrin (2011) who found that the quality of service has a positive and significant impact on taxpayer compliance. Their study indicates that good services increase taxpayer compliance in carrying out their tax obligations. This happens because taxpayers do not feel awkward to inquire about the implementation of tax laws that have not understood, so the implementation has no obstacle.

\subsection{Effects of Education on Taxpayer Compliance}

Increasing knowledge about taxation is necessary as it is related to taxpayers' understanding of taxes and other matters relating to the existing tax system. Knowledge of taxation is greatly influenced by taxpayers' level of tax education. If taxpayers acquire an adequate education about taxation, then they will have no difficulty in implementing the rules related to tax obligations that must be implemented.

Several studies have also proven that a person's knowledge affects his or her adherence. This is in line with the findings of Mukasa (2011), which show that tax knowledge has a causal relationship with tax compliance. Other researchers, such as Muklis, Utomo, and Susetio (2015), also found that taxation education increases the knowledge of taxpayers and has an impact on increasing taxpayer compliance in carrying out their tax obligations. According to Gitaru (2017), expertise and knowledge from education and training are required to improve taxpayer compliance in carrying out their tax obligations. Thus, the higher the knowledge of taxpayers, the more obedient they comply with rules (Ahmed, Zin \& Majid, 2016). Another study conducted by Machogu and Amayi (2013) found that the level of education of taxpayers affect the level of compliance in paying taxes. The better the understanding of taxpayers, the more obedient the taxpayers to carry out their tax obligations (Ali \& Haseeb, 2019). Therefore, the role of education in improving taxpayer compliance should be analyzed. The extent to which education plays a role in improving taxpayer compliance in carrying out their tax obligations needs to be explored.

On the basis of these explanations, the following hypothesis is derived:

H1: Education affects taxpayer compliance.

\subsection{Effects of Service Quality on Taxpayer Compliance}

Service quality plays a role that is not less important than education. Good and adequate service provided by tax authorities reduce the reluctance of taxpayers to communicate with tax authorities associated with the implementation of tax obligations. When a person feels comfortable and satisfied with the services provided by the tax officers, they will be motivated to comply with their tax obligations. Thus, the better the services provided by the tax officers, the higher the level of taxpayer compliance. This is in line with the findings of Alabede, Idris, and Affrin (2011) who found that service quality has a positive and significant impact on taxpayer compliance. In addition, the taxpayer does not feel awkward to inquire about the implementation of tax laws that they do not understand.

H2: Service quality affects taxpayer compliance 


\subsection{Effects of Accountability on Taxpayer Compliance}

Positive assessment of the taxpayer community on the application of government functions mobilizes them to comply with tax obligations. Accountability of public services is a new paradigm in answering the different perceptions of services desired by the community with services provided by the local government. Public services must be accountable, both to the public and to the head of the service unit of government agencies, in accordance with the provisions of the rules of organization legislation. Accountability of public services is the ability to serve taxpayers to meet all their needs in a transparent and open manner.

Susilawati and Budiartha (2013) found that accountability of public services has a positive and significant impact on compliance. Another study conducted by Modugu et al (2012) found that government accountability is an instrumental factor that affects the incidence of voluntary tax compliance. The findings indicate that if taxpayers perceive that the government, in this case, the Director General of Taxation, is highly accountable, then the level of taxpayer compliance tax to carry out their tax obligations will increase. Moreover, the more accountable service tax officers to taxpayers, the higher the level of taxpayer compliance.

H3: Accountability affects tax compliance.

\subsection{Moderating Role of Awareness}

Taxpayers need to have tax awareness to know and understand its issues and comply with tax obligations. Taxpayers' awareness in paying taxes is an attitude regarding views or feelings that involve knowledge of beliefs and reasoning, which impact the tendency to act in accordance with the stimulus provided by the tax system and provisions. Taxpayers are aware of their tax obligations carry out their tax obligations well, thus increasing the level of tax compliance.

Mukasa (2011, Kamil (2015), Suyanto and Trisnawati (2016), Nkiru, Sidi \& Abomeh (2018) found that tax awareness has a positive and significant impact on taxpayer compliance. Taxpayers that have an adequate level of education will better understand the system and rules of taxation better. With sufficient understanding, taxpayers will be motivated to comply with and carry out their tax obligations. Thus, the higher level of taxpayer education, especially in the field of taxation, the more obedient the taxpayers in carrying out their obligations.

Good service quality increases the willingness of taxpayers in fulfilling their tax obligations, which consequently increases taxpayer compliance. Similarly, the more accountable the tax institutions are according to the perception of taxpayers, the more obedient the taxpayers in complying with their taxation obligations.

If a taxpayer also has enough awareness of his obligations, the influence of education, service quality, and accountability of perceived taxpayers against taxpayer compliance level increases. Taxpayer awareness results in high levels of taxpayer compliance, which is affected by inadequate education, good service quality of tax authorities, and accountability of tax institutions as perceived by taxpayers. Savitri and Andtreas (2015) found that the quality of tax services affects tax compliance through tax awareness. Thus, if the taxpayer is aware of his tax obligations, then he/she will comply to carry out his tax obligations (Nguyen, 2018).

H4: Tax awareness moderates the effects of education on taxpayer compliance.

H5: Tax awareness moderates the effects of service quality on taxpayer compliance.

H6: Tax awareness moderates the effects of accountability on tax compliance.

\section{Methodology}

\subsection{Research Questions}

As indicated in the introduction, this study has two major research questions: to find out whether education, service quality, and accountability affect taxpayer compliance and to examine the moderating role of education, service quality, and accountability on taxpayer compliance.

\subsection{Modeling Volatility}

This study used multiple regression analysis to investigate the effects of education, service quality, and accountability on taxpayer compliance. To investigate the moderating effects of awareness, we used moderated regression analysis (Gozali, 2013). The model used for the analysis of $\mathrm{H} 1, \mathrm{H} 2$, and $\mathrm{H} 3$ is as follows:

$$
\text { TaxCompl }=\alpha+\beta 1 \text { Educ }+\beta 2 \text { ServQuak }+\beta 3 \text { Account } \varepsilon .
$$

The model used for H4, H5, and $\mathrm{H} 6$ is as follows:

$$
\text { H4: TaxCompl }=\alpha+\beta 1 \text { Educ }+\beta 2 \text { Awarns }+\beta 3 \text { Educ*Awarns }+\varepsilon
$$




$$
\begin{gathered}
\text { TaxCompl }=\alpha+\beta 1 \text { Educ }+\beta 2 \text { Educ*Awarns }+\varepsilon \\
\text { H5: TaxCompl }=\alpha+\beta 1 \text { ServQual }+\beta 2 \text { Awarns }+\beta 3 \text { ServQual*Awarns }+\varepsilon \\
\text { TaxCompl }=\alpha+\beta 1 \text { ServQual }+\beta 2 \text { ServQual*Awarns }+\varepsilon \\
\text { H6: TaxCompl }=\alpha+\beta 1 \text { Account }+\beta 2 \text { Awarns }+\beta 3 \text { Account*Awarns }+\varepsilon \\
\text { TaxCompl }=\alpha+\beta 1 \text { Account }+\beta 2 \text { Account*TaxAwarns }+\varepsilon
\end{gathered}
$$

\subsection{Data Collection}

In this study, the data were obtained from the taxpayers listed on the Directorate General of Taxation in Riau, Indonesia. The data to be processed are the taxpayers' answers, which act as the respondents, on the distributed questionnaire. The number of returned questionnaires, which were further processed, is 253 sheets.

\subsubsection{Data Analysis Technique}

We started by variable definition, measures, and methods (formulas) that will be used. As described earlier, the study used multiple regression and moderated regression analyses to test the hypotheses.

\subsection{Definition and Variables Measurement}

Variables of this research consist of taxpayer compliance as dependent variable and education, service quality, and accountability as independent variables. The moderating variable is tax awareness. Education is defined as the process of training in the field of taxation passed by the taxpayers, which can be used by taxpayers to carry out their tax obligations. Service quality is the quality of service provided to the community, which will cause a sense of satisfaction or dissatisfaction for the community or consumers. The quality of public services can also be interpreted as the state of a good or service that quality is determined when the public service is given (Ibrahim, 2008: 22). Taxpayer compliance is measured by five questions that were adopted from Rika \& Rahmadani (2013), education is measured in four questions (Ernawati, 2014), service quality was adopted from Syahril (2013) with seven questions, and accountability with four questions (Muhammad Adnan Hye 2012; Yuskar \& Resi, 2013) in a five-point Likert scale.

\subsection{Classic Assumption Test}

To obtain the results of data analysis that qualify the test, the study carried out classical assumption for statistical testing.

\subsubsection{Normality Test}

Normality test aims to test the method regression of dependent variables. Variable and independent variables have either normal distribution or not (Muhammad Adnan Hye \& Dolgopolova 2011; Ghozali, 2013). A good regression model is composed of data that have a normal distribution. Normality test was performed using KolmogorovSmirnov test. If the value of significance is above 0.05 , then the data have a normal distribution. The results of normality test data shown in Table 3.1 show that the significance value is greater than 0.05 . Thus, the data have a normal distribution.

\subsubsection{Normality Test Result}

One-Sample Kolmogorov-Smirnov Test

\begin{tabular}{|ll|r|}
\hline \multicolumn{2}{|c|}{ One-Sample Kolmogorov-Smirnov Test } \\
\hline N & $\begin{array}{r}\text { Unstandardized } \\
\text { Residual }\end{array}$ \\
Normal Parameters ${ }^{\mathrm{a}, \mathrm{b}}$ & Mean & 253 \\
& Std. Deviation & -.1877603 \\
Most Extreme Differences & Absolute & 1.77121350 \\
& Positive & .051 \\
& Negative & .041 \\
Test Statistic & & -.051 \\
Asymp. Sig. (2-tailed) & & .051 \\
& & $.200^{\mathrm{c}, \mathrm{d}}$ \\
\hline
\end{tabular}

a. Test distribution is Normal.

b. Calculated from data.

c. Lilliefors Significance Correction.

d. This is a lower bound of the true significance. 


\subsubsection{Multicollinearity Test}

Multicollinearity test was conducted to determine whether a correlation exists between independent variables on the regression model. A good regression model should not have correlation between independent variables (Ghozali, 2013). The presence or absence of multicollinearity in the regression model seen from the tolerance value and the value of variance inflation factor (VIF) should be detected.

Table 1 show that all independent variables have a tolerance value $>0.10$ and VIF value $<10$. Therefore, the independent variables used in the regression model of this study are free from multicollinearity problems.

Table 1. Tolerance and VIF value

\begin{tabular}{lll}
\hline Variables & Tolerance & VIF \\
\hline Educ & 0.880 & 1.136 \\
\hline ServQual & 0.581 & 1.721 \\
\hline Account & 0.538 & 1.859 \\
\hline Awarns & 0.527 & 1.897 \\
\hline
\end{tabular}

\subsubsection{Heteroscedasticity Test}

Heteroscedasticity test aims to test whether the regression model occurs in variance uniformity of one residual observation to another observation. A good regression model has no heteroscedasticity (Muhammad Adnan Hye \& Wizarat 2011; Ghozali, 2013). To detect the presence or absence of heteroscedasticity, the study used scatterplot chart method.

Figure 1 shows that the points on the image do not form a certain pattern. The data spread above and below 0 on the $\mathrm{Y}$ axis indicates that the model does not have heteroscedasticity. This finding means that the sample variance from residual observation to other observations has similarities that can be efficient. Thus, based on the classical assumption test results obtained, the free model of autocorrelation, multicollinearity, and heteroscedasticity are feasible to be used as a model in this study.

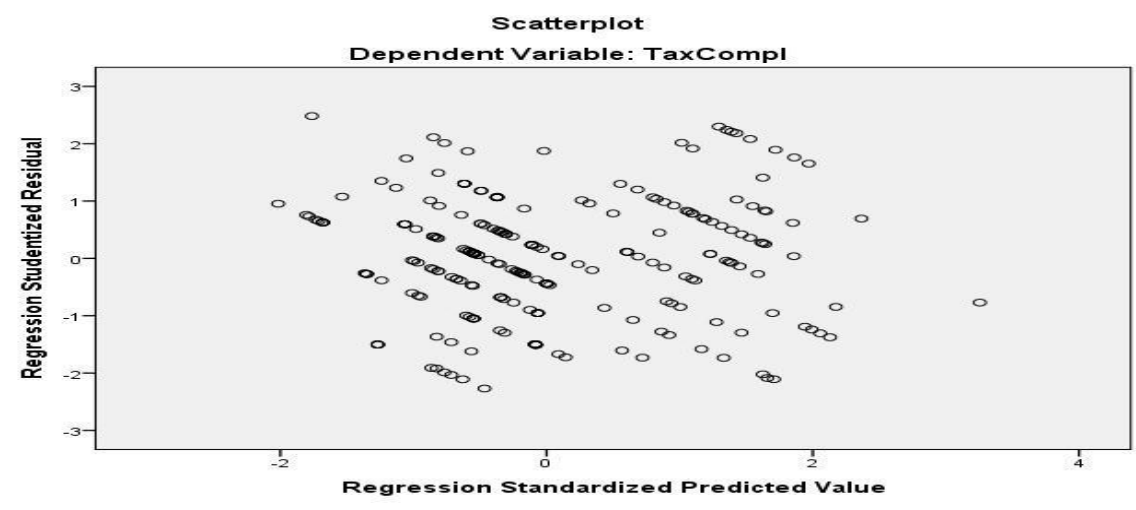

Figure 1. Scatterplot

\subsubsection{Autocorrelation Test}

Autocorrelation is a symptom of correlation between the errors of an observer from other observations. Autocorrelation arises because of sequential and related observations. To test whether autocorrelation exists, the variables were measured using Durbin Watson (DW) statistics. Based on the results in Table 4.3, the Durbin-Watson value is 2,000 and the value is between DW -2 and +2 , which means that no autocorrelation exists. Thus, no problem of autocorrelation in the regression model was formed in this study. 
Table 2. Durbin-Watson Value

\begin{tabular}{llllll}
\hline Model & $\mathrm{R}$ & R Square & Adj R Square & F Change & Durbin-Watson \\
\hline 1 & $0.697^{\mathrm{a}}$ & 0.486 & 0.478 & 58.672 & 2.000 \\
\hline
\end{tabular}

\section{Results and Discussion}

Regression analysis is used in this study, where all independent variables are used to explain the dependent variable. This study used $\alpha=5 \%$, which means the probability of error should only be small or equal to $5 \%$. If the value is more than 0.05, then the regression model is not feasible for use. Based on the SPSS output, the partial effect of institutional ownership and firm size on firm value is shown in the following table:

Table 3. T and P value

\begin{tabular}{|c|c|c|c|c|}
\hline \multirow[t]{2}{*}{ Model } & \multicolumn{2}{|c|}{ Unstandardized Coefficient } & \multicolumn{2}{|c|}{ Standardized Coefficient } \\
\hline & $\mathrm{B}$ & Std Error & Beta & $P$ value \\
\hline (Constant) & 18.898 & 1.881 & & \\
\hline Educ & 0.349 & 0.086 & 0.196 & 0.000 \\
\hline ServQual & 0.495 & 0.041 & 0.617 & 0.000 \\
\hline Account & 0.013 & 0.074 & 0.008 & 0.001 \\
\hline
\end{tabular}

Source: Processed Data

Table 3 shows that the $\mathrm{P}$ value of the effect education on taxpayer compliance is 0.00 , which is smaller than 0.05 and thus has a significant effect. A positive beta sign indicates that the better a taxpayer's education, the more obedient the taxpayer will be in carrying out his tax obligations. If the taxpayer gets a good tax education, then the taxpayer will feel no obstacles or difficulties in carrying out tax obligations. Taxpayers who understand the rules of taxation well is motivated in meeting his tax obligations. Education has an impact on increasing taxpayer compliance. These findings are in line with Mukhlis et al. (2015), Susetio (2015), and Gitaru (2017).

The test results of the effect of service quality on taxpayer compliance shows a $P$ value of 0.00 , which is smaller than 0.05 and thus has a positive beta sign. These findings indicate that service quality affects taxpayer compliance. The better the service quality provided by the tax authorities, the more obedient the taxpayers in carrying out his tax obligations. Good service quality will cause taxpayers to not be reluctant to communicate with tax authorities as regards the implementation of tax obligations. Alabede et al. (2011) and Awaluddin and Tamburaka (2017) also found that the better the service quality provided to the taxpayers, the higher the taxpayers' obedience in paying taxes.

This study also found that accountability affects taxpayer compliance with a $\mathrm{P}$ value of 0.005 . Thus, more accountability does not affect taxpayer compliance. This finding is in line with Susilawati and Budiartha (2013) and Adeyeye and Otusanya (2015), who found that public service accountability has a positive and significant impact on compliance. Modugu et al. (2012) also found that government accountability is an instrumental factor, resulting in the incidence of voluntary tax compliance. Thus, if the taxpayers perceive that the government, in this case the Director General of Taxation, is highly accountable, then the level of taxpayer compliance tax to carry out its tax obligations increases. Moreover, the more accountable service tax officers to taxpayers, the higher the level of taxpayer compliance in carrying out its tax obligations.

$\mathrm{H} 4, \mathrm{H} 5$, and $\mathrm{H} 6$ aim to examine the moderating effects of education, service quality, and accountability on tax compliance. The test results of moderation regression model found that tax awareness as a pure moderation variable because the test result using quasi moderating result shows a $\mathrm{P}$ value of tax awareness equal to 0.196 (not significant) (Table 4). Therefore, tax awareness was tested as a pure moderator. 
Table 4. Moderating variable test result

\begin{tabular}{llllll}
\hline Model & \multicolumn{2}{l}{ Unstandardized Coefficient } & Standardized Coefficient & \\
\hline & $\mathrm{B}$ & Std Error & Beta & $t$ & P value \\
\hline (Constant) & 20.263 & 2.153 & & 3.866 & 0.000 \\
\hline Educ & 0.333 & 0.086 & 0.188 & 9.644 & 0.000 \\
\hline ServQual & 0.463 & 0.048 & 0.576 & 0.663 & 0.508 \\
\hline Account & 0.062 & 0.094 & 0.041 & 1.297 & 0.196 \\
\hline Awarn & 0.050 & 0.038 & 0.081 & & \\
\hline
\end{tabular}

Source: Processed data

Test results using moderated regression analysis indicate that tax awareness moderates the effects of education, service quality, and accountability on tax compliance. A positive beta value indicates that awareness strengthens the effects of education, service quality, and accountability on tax compliance. Taxpayers' awareness of their obligations to comply with the prevailing rules further strengthens the effects of education, service quality, and accountability on taxpayer compliance.

Taxpayers need to be aware of their tax obligations, taxation issues, and taxes to fulfill their tax obligations well. Taxpayer awareness is a behavior that involves knowledge, conviction, and reasoning, accompanied by a tendency to act in accordance with the stimulus provided by the system and the tax provisions. Taxpayers who have tax awareness will carry out their tax obligations well, which consequently have an impact on increasing tax compliance levels. The results of this study are in line with the findings of Suyanto and Trisnawati (2016) who also found that tax awareness has a positive and significant impact on taxpayer compliance.

Taxpayers who have an adequate education level will better understand the system and rules of taxation better. They will also be motivated to carry out their tax obligations, including paying taxes. Thus, the higher the level of taxpayer education, especially in the field of taxation, the more obedient the taxpayers in carrying out their obligations.

The present study also found that awareness affects the effects of service quality on taxpayer compliance. The better the quality of service, the more obedient the taxpayers in fulfilling his tax obligations. Taxpayers' awareness on the need to fulfill their taxation obligations will further improve taxpayer compliance. This is due to the satisfactory services provided by tax authorities. Good service quality will increase the interest of taxpayers in fulfilling their tax obligations. This will also have an impact on increasing taxpayer compliance to pay its tax debt.

This study also found that accountable tax institutions have an impact on the obedience of taxpayers to carry out their tax obligations. If the taxpayer also has a high awareness of his obligations (tax-conscious taxpayers), then the influence of education, service quality, and perceived accountability of taxpayers on taxpayer compliance level increases. Taxpayer awareness will result in high levels of taxpayer compliance due to adequate education, good service quality provided by tax authorities, and taxpayer accountability, which is perceived by the taxpayers. Savitri and Andtreas (2015) found that the quality of tax services affects tax compliance through tax awareness. Thus, if the taxpayer has an awareness of his tax obligations, then the taxpayer will comply to carry out his tax obligations.

\section{Conclution and Recommendation}

\subsection{Conclusion}

Currently, tax revenue is still not maximized, and the realization of such revenue has not reached the target that has been determined probably because taxpayer compliance is still not maximized in carrying out their tax obligations. Taxpayer education influences taxpayer compliance level. Moreover, taxpayer compliance is influenced by how the services provided by the tax authorities to the taxpayers itself. Tax institution's accountability also plays a role in determining taxpayer compliance level. In addition, the influence of the level of education, quality of service, and accountability of tax institutions on taxpayer compliance also depend on the consciousness of the taxpayers on their responsibilities.

\subsection{Recommendation}

On the basis of the results of the study, tax institutions should improve the quality of services provided to taxpayers. Adequate services provided to taxpayers will encourage and motivate then to carry out their tax obligations properly. 
They also have impact on the increase of tax revenue, thus achieving the target tax revenue. In addition, taxpayers should increase their knowledge on taxation through adequate education. If taxpayers have sufficient knowledge, then they will be motivated to carry out their tax obligations.

\section{References}

Adeyeye, B. G., \& Otusanya, J. O. (2015). The impact of taxpayers' perception of government's accountability, transparency and reduction in fiscal corruption on voluntary tax compliance in Nigeria. Int. J. Economics and Accounting, 6(3), 276-299. https://doi.org/10.1504/IJEA.2015.071817

Ahmed, U., Zin, M. L. M., \& Majid, A. H. A. (2016). Impact of Intention and Technology Awareness on Transport Industry's E-service: Evidence from an Emerging Economy. IJIDB, 7(3), 13-18. https://doi.org/10.13106/ijidb.2016.vol7.no3.13.

Alabede, J. O., \& Kamil Md Idris, A. (2011). Tax Service quality and compliance behavior in Nigeria: Do taxpayers financial condition and risk preference play any moderating role?. European Journal of Economics, Finance and Administrative Sciences, (35), 90-108.

Ali, A., \& Haseeb, M. (2019). Radio frequency identification (RFID) technology as a strategic tool towards higher performance of supply chain operations in textile and apparel industry of Malaysia. Uncertain Supply Chain Management, 7(2), 215-226. https://doi.org/10.5267/j.uscm.2018.10.004

Awaluddin, I., \& Tamburaka, S. (2017). The effect of service quality and taxpayer satisfaction on compliance payment tax motor. The International Journal of Engineering and Science (IJES), 6(1), 25-34.

Eisenhardt, K. M. (1989). Agency theory: An assesment and review. Academic of Management Review, 14, 57-74. https://doi.org/10.5465/amr.1989.4279003

Gitaru, K. (2017). The Effect of Taxpayer Education on Tax Compliance in Kenya (a case study of SME's in Nairobi Central Business District). Munich Personal RePEc Archive.

Gozali, I. (2013). Aplikasi analisis multivariate dengan program IBM, SPSS 21, update PLS regresi. Badan Penerbit Universitas Diponegoro, 7.

Jensen, M. C., \& W. H. Meckling. (1976) Theory of the firm: Managerial behavior, agency costs and ownership structure. Journal of Financial Economics, 3, 305-360. https://doi.org/10.1016/0304-405X(76)90026-X

Jermsittiparsert, K., \& Sriyakul, T. (2014). The Development of Population Potential and National Power by Elevating the Professional Standard for Sport Coaches. Asian Social Science, 10(10), 188-198. https://doi.org/10.5539/ass.v10n10p188

Kamil, N. I. (2015). The Effect of Taxpayer Awareness, Knowledge, Tax Penalties and Tax Authorities Services on the Tax Compliance: (Survey on the Individual Taxpayer at Jabodetabek \& Bandung). Research Journal of Finance and Accounting, 6(2), 104-11.

Kelley, H. H. (1967). Attribution Theory in Social Psychology. In D. Levine (Ed.), Nebraska Symposium on Motivation (Vol.15, pp. 129-238). Lincoln: University of Nebraska Press.

La Porta, R., Lopez-de-Silanes, F., Shleifer, A., \& Vishny, R. (2000). Investor protection and corporate governance. Journal of Financial Economics, 58, 3-27. https://doi.org/10.1016/S0304-405X(00)00065-9

Lilisen, V. R., \& Indrawari, N. (2018). The effect of taxation system, accountability and examination risk on the taxpayer compliance with taxpayer morale as a moderating variable. Pekbis Journal, 10(3), 209-223.

Machogu, C. G., \& Amayi, J. B. (2013). The effect of taxpayer education on voluntary tax compliance, among SMES Mwanza City-Tanzania. International Journal of Marketing, Financial Services \& Management Research, 2(8), 12-23.

Modugu, P. K., Eragbhe, E., \& Izedonmi, F. (2012). Government accountability and voluntary tax compliance in Nigeria. Research Journal of Finance and Accounting, 3(5), 69-72.

Muchlis, I., Sugeng, H. U., \& Soesetio, Y. (2015). The role of taxation education on taxation knowledge and its effect on tax fairness as well as tax compliance on handicraft SMEs sectors in Indonesia. International Journal of Financial Research, 6(4), 161-169. https://doi.org/10.5430/ijfr.v6n4p161

Muhammad Adnan Hye, Q. (2012). Exports, imports and economic growth in China: an ARDL analysis. Journal of Chinese Economic and Foreign Trade Studies, 5(1), 42-55. https://doi.org/10.1108/17544401211197959 
Muhammad Adnan Hye, Q., \& Dolgopolova, I. (2011). Economics, finance and development in China: Johansen-Juselius co-integration approach. Chinese Management Studies, 5(3), 311-324. https://doi.org/10.1108/17506141111163381

Muhammad Adnan Hye, Q., \& Wizarat, S. (2011). Impact of financial liberalization on agricultural growth: a case study of Pakistan. China Agricultural Economic Review, 3(2), 191-209. https://doi.org/10.1108/17561371111131317

Mukasa, J. (2011). Tax knowledge, perceived tax fairness and tax compliance in Uganda the case of mmall and medium income taxpayers in Kampala Central Division. Dissertation, Makerere University, Uganda.

Negrut, V. (2017). Overview of the Most Common Types of Maladministration Raised at EU Level. International Journal of Public Policy and Administration Research, 4(2), 35-40. https://doi.org/10.18488/journal.74.2017.42.35.40

Nejad, M. A. R. S., Agha, F. N. J., \& Zadeh, Y. F. (2017). QSPM Usage in SWOT Analysis as a Tool for Strategic Management of Caspian Sea Coasts (Case Study: Tourism Development in Caspian Eastern Coast at Gilan Province). Journal of Tourism Management Research, 4(1), 1-11. https://doi.org/10.18488/journal.31.2017.41.1.11

Nguyen, A. T. (2018). The Relationship among Economic Growth, Trade, Unemployment, and Inflation in South Asia: A Vector Autoregressive Model Approach. Asian Journal of Economics and Empirical Research, 5(2), 165-172. https://doi.org/10.20448/journal.501.2018.52.165.172

Nkiru, N., Sidi, C. P., \& Abomeh, S. (2018). Impact of Information and Communication Technology on the Performance of Deposit Money Banks in Nigeria. International Journal of Management, 7(4), 225-239. https://doi.org/10.18488/journal.11.2018.74.225.239

Nurulhuda, S., Hasan, R., \& Mohd, A. (2018). Does Gold Price Lead or Lags Islamic Stock Market and Strategy Commodity Price? A Study from Malaysia. International Journal of Business, 5(6), 146-163. https://doi.org/10.18488/journal.62.2018.56.146.163

Robbins, S. (1996). Organizational behavior: Concepts, controversies, and applications. Prentice Hall International editions.

Savitri, E., \& Musfialdy. (2016). The Effect of Taxpayer awareness, tax socialization, tax penalties, compliance cost at taxpayer compliance with service quality as mediating variable. Procedia - Social and Behavioral Sciences, 219, 682-687. https://doi.org/10.1016/j.sbspro.2016.05.051

Savitri, E., \& Andreas. (2015). The effect of tax socialization, tax knowledge, expediency of tax ID number and service quality on taxpayers compliance with taxpayers awareness as mediating variables. Procedia-Social and Behavioral Science, 211, 163-168. https://doi.org/10.1016/j.sbspro.2015.11.024

Susilawati, K. E., \& Budiartha. (2013). The effect of taxpayer awareness, tax knowledge, taxation sanction, and public service accountability on tax Compliance on vehicles taxpayer compliance. E-Journal Accounting of Universities Udayana, 4(2), 345-357.

Suyanto, T. (2016). The Influence of Taxpayer awareness toward tax compliance of entrepreneurial taxpayers an celengan padjeg program as moderating variable: case study at the Pratama Tax Office of Wonosari Town. INFERENSI, Journal Religious Social Research, 10(1), 47-68. https://doi.org/10.18326/infs13.v10i1.47-68 